DOI https://doi.org/10.30525/978-9934-26-073-5-2-24

\title{
ПЕРЕКЛАД ПРИКМЕТНИКІВ АНГЛІЙСЬКОЇ МОВИ BEAUTIFUL, HANDSOME, FAIR, LOVELY, GOOD - LOOKING, PRETTY («КРАСИВИЙ», «ГАРНИЙ», «ПРЕКРАСНИЙ») НА ПРИКЛАДІ ТВОРІВ 3 ХУДОЖНЬОЇ ЛІТЕРАТУРИ
}

\author{
Бондаренко О. I. \\ викладач кафедри англійської мови гуманітарного спрямування № 3 \\ факультету лінгвістики \\ Національного технічного університету України \\ «Київький політехнічний інститут імені Ігоря Сікорського» \\ м. Київ, Украӥна
}

Ці слова розрізнюються за додатковою характеристикою поняття, що вони висловлюють.

Beautiful має смисловий відтінок, який «справляє приємне враження», «приносить естетичну насолоду», «приємний для ока, для слуху»: a beautiful woman, thing, scene, figure - красива жінка, річ, пейзаж, фігура; beautiful music, voice, song - гарна (-ий) музика, голос, пісня: Не cared for beautiful things (Oscar Wilde) - Він любив гарні речі. What a beautiful voice you have! (Bernard Shaw) - Який у Вас гарний голос!

Прикметник beautiful вживається тільки по відношенню до жінки: Don't you think that boy's mother is the most beautiful woman of her age you've ever seen (Galsworthy). - Як на мене, мати того хлопчика найгарніша зі всіх жінок ії віку, яку я коли - небудь бачила. У випадках, коли мова йде про дітей, цей прикметник вживається по відношенню як i до хлопчика, так і до дівчинки: We were welcomed by a most beautiful girl (Charles Dickens). - Нас радо зустріла дуже красива дівчинка. ....asked Amelia about that beautiful boy who had been within (Thackeray). - ... запитали Амелію про того красивого хлопчика, який був в будинку. В розмовній мові прикметник beautiful може мати значення «дуже гарний», «чудовий», тому у цьому значенні воно у вищезазначений синонімічний ряд не входить: The next day it was bright, beautiful weather. - Наступного дня була ясна, чудова погода [1, с. 20-21].

Handsome має смисловий відтінок, який «справляє приємне враження правильністю пропорцій, правильними рисами, поєднанням тонів»: a handsome man, house - гарний чоловік, дім: He was very young and handsome (Bernard Shaw). - Він був дуже молодим та гарним. Цей прикметник зазвичай вживається по відношенню до людини чоловічої 98 
статі: Не was handsome man with blue eyes and fair hair. - Він був красивий чоловік з блакитними очима і білявим волоссям. Однак, його можна вжити і по відношенню до жінки, але лише тоді, коли цей прикметник втрачає емоційне забарвлення і вказує лише на правильність пропорцій фігури жінки або на правильність рис обличчя: Would you describe that lady as beautiful or handsome (Hornby). - Ви знаходите цю жінку красивою або прекрасною? Слід взяти до уваги: цей прикметник може мати значення «значний» (a handsome sum, present) i «великодушний» (a handsome compliment).

Fair має смисловий відтінок, який вказує на красу, пов'язану iз внутрішньою чистотою, свіжістю, молодістю; на щось, що має характер світлого та веселого. Цей прикметник, на відміну від вищезгаданих, привносить в судження елемент суб'єктивності: After supper Allan sang sweet songs to the fair guest as she sat by Robin's side. - Після вечері Алан співав мелодичні пісні прекрасній гості, яка сиділа поряд із Робіном [1, с. 22].

Lovely підкреслює не стільки об'єктивну естетичну цінність, якою визначається, скільки емоціональне сприйняття того, хто говорить, і вживається по відношенню до того, що викликає почуття захоплення. В розмовній мові цей прикметник зазвичай має значення «чудовий», «чарівний», «приємний»: He said you had a lovely house (Galsworthy). Він сказав, що у вас чудовий будинок. She is very pretty - very. In fact, she's lovely (Thomas Hardy). - Вона дуже гарненька - дуже. Власне, вона чарівна. Також, цей прикметник може мати значення «веселий», «цікавий»: to have a lovely time - весело проводити час; a lovely joke цікавий жарт; a lovely party - веселий вечір: Mr. Lewes had a lovely time at Weybridge (Elliot). - Містер Л’юїс провів дуже весело час у Уейбріджі. What a lovely joke (Hornby). - Який веселий жарт! [1, c. 23]

Good - looking має смисловий відтінок, який вказує на гарну, приємна зовнішність; вживається тільки по відношенню до людей: She never told me he was so good - looking (Oscar Wilde). - Вона ніколи не говорила мені, що він такий гарний собою.

Pretty має смисловий відтінок, який вказує просто на зовнішній вигляд, привабливий внаслідок ніжності, витонченості, вишуканості і іноді жіночності. Зазвичай вживається по відношенню до чого - небудь або кого - небудь порівняно невеликому, маленькому: a pretty girl, a pretty child, a pretty little garden - гарненька дівчинка, дитина, садочок: Is your sister - in - law a nice pretty woman? - Ваша невістка приємна гарненька жінка? A pretty little house stood at the top of the lane with a garden before it (Charlotte Bronte). - Гарненький маленький будиночок із 
садочком стояв в кінці алеї. Не слід змішувати прикметник pretty 3 прислівником pretty, який має значення «досить», «доволі» і поєднується тільки з прикметниками і прислівниками: pretty hot - досить жарко; pretty much - доволі багато: He himself was a good steady workman, and, as such, pretty certain of steady employment. - Він був хорошим робочим i, як такий, був досить впевнений у постійній роботі [1, с. 24].

\title{
Література:
}

1. Потапова I.О. Короткий словник синонімів англійської мови. Л.: Державне учбово - педагогічне видавництво міністерства освіти РРФСР, Ленінградське відділення, 1957. С. 20-24.

DOI https://doi.org/10.30525/978-9934-26-073-5-2-25

\section{ОСОБЛИВОСТІ ПЕРЕКЛАДУ ІНТЕРНАЦІОНАЛІЗМІВ У НАУКОВО-ТЕХНІЧНИХ ТЕКСТАХ}

\author{
Гончарова В. Б.
}

викладач

Відокремленого структурного підрозділу

«Херсонський політехнічний фаховий коледж

Державного університету "Одеська політехніка»

\section{Пестушко А. В. викладач}

Відокремленого структурного підрозділу «Херсонський політехнічний фаховий коледж Державного університету «Одеська політехніка» м. Херсон, Україна

Складним $є$ питання про переклад міжнародних стандартів і псевдоінтернаціональних слів. Науковий стиль - це один 3 функціональних стилів загальнолітературної мови, який обслуговує сферу науки i виробництва. У всіх наукових текстах зустрічається великий відсоток інтернаціональних слів. Технічний та науковий процес перекладу потребує від перекладача високий рівень володіння іноземними мовами, необхідними знаннями в сферах теми перекладу і вільної орієнтації в науково-технічній термінології. 